\title{
Thirty Years' Quest for Emission Reduction and Energy Efficiency Improvement of Brick Kilns in Bangladesh
}

\author{
Mohammed Khaliquzzaman ${ }^{1,}$, , Appalarajugari Sesha Harinath², Shakil Ahmed Ferdousi', \\ Salim Mohammed Munjurul Hannan Khan ${ }^{3}$ \\ ${ }^{1}$ Environment Team, World Bank Office, Dhaka, Bangladesh \\ ${ }^{2}$ Environmental and Natural Resources Global Practice, The World Bank, Washington DC, USA \\ ${ }^{3}$ MOEFCC (Ministry of Environment, Forest and Climate Change), Government of Bangladesh, Dhaka, Bangladesh
}

Email address:

dkhaliquzzaman@worldbank.org (M. Khaliquzzaman), harinath@worldbank.org (A. S. Harinath), sferdausi@worldbank.org (S. A. Ferdousi), munjurulkhan@gmail.com (S. M. M. H. Khan)

${ }^{*}$ Corresponding author

\section{To cite this article:}

Mohammed Khaliquzzaman, Appalarajugari Sesha Harinath, Shakil Ahmed Ferdousi, Salim Mohammed Munjurul Hannan Khan. Thirty Years' Quest for Emission Reduction and Energy Efficiency Improvement of Brick Kilns in Bangladesh. International Journal of Environmental Monitoring and Analysis. Vol. 8, No. 1, 2020, pp. 11-22. doi: 10.11648/j.ijema.20200801.12

Received: February 6, 2020; Accepted: February 24, 2020; Published: March 10, 2020

\begin{abstract}
Brick kilns have been the backbone of the construction industry in Bangladesh due to non-availability of stones in enough quantity. Brick kilns in the country use age-old technologies, which are inefficient with high emissions. In addition, the industry uses low quality of coal as fuel, with high ash and sulfur content; there by contributing to the worsening of air quality. This paper discusses the developments in brick making during the past 30 years in search of higher energy efficiency and lower pollution. It is seen that the progress in pollution abatement and energy efficiency improvement have been slow; resulting in considerable health burden for the population and other economic losses for a long time. In recent years, some affordable designs of low polluting and more energy efficient kilns have been introduced by the Department of Environment (DOE) through a number of programs; including World Bank financed Clean Air and Sustainable Environment (CASE) Project. These efforts have led to considerable pollution reduction i.e., by more than $70 \%$ for PM (Particulate Matter) and coal consumption reduction by around $30 \%$ at individual brick kiln level. Large low emission industrial kilns with imported technology are also being established. However, the rollout of these energy efficient and low emission technologies in substantial numbers is yet to be achieved. Some moves are also afoot to increase the use of non-fired bricks. In order to achieve quick all-round gains, both push as pull factors for the change in current situation need to be mobilized. What is needed is a well-articulated time bound 'Theory of Change (ToC)' for green and clean brick industry in the country. Success in this endeavor will substantially reduce the air pollution levels bringing health benefits to local population. Concurrently, it will also reduce the land-use footprint, top soil use, loss of agricultural productivity and Green House Gas (GHG) emission from the brick kilns. In addition, this will also improve employment and working conditions for labor employed in the brick sector. A simplified $\mathrm{ToC}$ for a cleaner and greener brick sector for a ten years' period is outlined in this work.
\end{abstract}

Keywords: Brick Kiln, Energy Efficiency, Low Emission, Air Pollution, Particulate Matter, GHG Emission, Health, Top Soil, Theory of Change

\section{Introduction}

Brick kilns have been the backbone of the construction industry in Bangladesh since stones are not readily available in required quantity. According to the latest survey data [1], the total number of brick kilns in the country is $7,902^{1}$ with different technology mix discussed in section-3. The manpower employed is around one million, who are mostly seasonal workers; working for 4-5 months (December-April)

1 This 2018 inventory shows that of the 7902 kilns, 631 have been found to be inoperative. 
in the year. The total bricks produced per year is estimated at about 31 billion and valued at $\$ 3.6$ billion; which is about $1.3 \%$ GDP (i.e., GDP of $\$ 274$ billion in 2018$)^{2}$. Earliest brick kilns in the country were mainly Clamps and of Bull Trench Kilns (BTK) ${ }^{3}$ type. More details on the different types of kiln technologies are given in section-3. Brick kilns in Bangladesh have been highly polluting, because of the use of inefficient technologies and low quality of coal as fuel, with high ash and sulfur content. It is about 30 years now, that Government of Bangladesh (GOB) first tried to regulate brick kilns by adopting various regulatory measures; starting with the Brick Burning Act (1989) and others measures since then. These regulatory measures had only limited success so far. The impact of the pollution from brick kilns is accentuated by the fact that the brick burning season coincides with the dry season; when ambient particulate concentrations are at their peak all over the country.

GOB has undertaken renewed initiative in recent years to reduce air pollution from the Brick kilns; including move to more energy efficient and cleaner technologies. The fixed chimney kilns (FCK) ${ }^{4}$ have been the mainstay in the Bangladesh brick manufacturing; due to low investment cost and high profitability. As standardized designs for cleaner kilns which can replace FCKs have not been available in the market; the DOE (Department of Environment), GOB undertook the development of standard designs of similar production capacity kilns; which are more energy efficient and cleaner, while at same time reasonably priced for adoption by the existing FCK entrepreneurs. The outcomes from the initiative have resulted in substantial progress in energy efficiency improvement (i.e., around 30-40\%) and emission reduction (i.e., $>70 \%$ ). These are improved version of a traditional Zigzag (TZigzag) kiln referred to as IZigzag (Improved Zigzag) Kilns [2]; and a miniature version of Hybrid Hoffman Kiln (MHHK) [3]. These have been piloted in a limited scale with promising results. Another two models i.e., a VSBK (Vertical Shaft Brick Kiln) [4] and a mini Tunnel Kiln (MTK) [3] have also been developed in the DOE program. Piloting of one VSBK was done, but it did not find acceptability among kiln owners and MTK is yet to be piloted. All these brick kiln models are discussed briefly in section-3.

In parallel, introduction of newer larger capacity technologies, mainly from China has been going on for about 15 years now. These are large kilns with production capacity around 100,000 bricks per day and even more, based on Hybrid Hoffman kiln (HHK) and Tunnel kiln (TK) designs [4]. However, these only accounts so far, for a small fraction of the brick produced in the country. Even with better technologies, optimal benefits can only be obtained with their

2 Available brick data have been updated using information from this 2018 inventory.

3 In a CLAMP, green bricks are stacked with fuel (wood/coal) in the traditional manner and fired from the bottom; once the fire burns out bricks are removed. Bull trench kilns (BTK) are continuous production elliptical kilns with movable chimneys (usually $30 \mathrm{ft}$ high) and a moving fire zone.

4 The FCK is an improved version BTK with a $120 \mathrm{ft}$ chimney at the center of the kiln. proper implementation. So, strategies for deployment and other synergistic policies, which can substantially boost the energy savings and emission reduction benefits are discussed here. There are likely to be some unintended and unexpected outcomes also in the implementation of the newer technologies and policies; and these issues need to be addressed through remedial actions during implementation.

\section{Developments in Brick Kilns' Regulations in Bangladesh}

Traditionally commercial brick production in the country was based on Bull Trench Kilns with movable sheet-metal chimneys. Because of movability requirement, the chimneys were only 610 meters high. The result was extremely high local smoke pollution impacting both public health and agricultural production negatively. This gave rise to resentments among population in the vicinity of the brick kilns. The brick sector regulatory developments started with the passage of the Brick Burning Act of $1989^{5}$. The regulatory developments since then are summarized in table 1. Under regulatory pressure (e.g., withholding of DOE clearance), the kiln owners stared moving to Fixed Chimney kilns (FCKs) with $120 \mathrm{ft}$ chimney (made compulsory in 2002); which abated the local pollution to some extent. In 2010, a further notification banning FCKs and move to cleaner technologies mandatory by 2013 was issued. As a result, the kiln owners started moving to traditional Zigzag (TZigzag) kilns; as this was the only low-cost option available at the time. The TZigzag design was imported from India and gets its name from the zigzag air flow in the kiln. These were implemented using artisans with limited skills and without standardized designs. Naturally, the sizes and production capacity varied depending on the artisans' experience used in construction. These kilns are rectangular in shape; with chimney on one side with the height of 55 feet in most cases.

Table 1. Regulatory developments in the brick sector in Bangladesh.

\begin{tabular}{|c|c|c|}
\hline Year & $\begin{array}{l}\text { Policies, laws, and } \\
\text { regulations }\end{array}$ & Comments \\
\hline 1989 & $\begin{array}{l}\text { The Brick Burning } \\
\text { (Regulation) Act of } \\
1989^{5}\end{array}$ & $\begin{array}{l}\text { Bangladesh's first brick-making law, banned } \\
\text { the use of firewood for brick manufacturing } \\
\text { and introduced licensing for brick kilns. }\end{array}$ \\
\hline 1997 & $\begin{array}{l}\text { Environmental } \\
\text { Conservation Rules }^{6}\end{array}$ & $\begin{array}{l}\text { Sets limit for brick kiln SPM emission at } \\
1000 \mathrm{mg} / \mathrm{m}^{3} \text {. }\end{array}$ \\
\hline 2002 & $\begin{array}{l}\text { GOB Rule on brick } \\
\text { kiln introduced in } \\
\text { October, } 2002\end{array}$ & $\begin{array}{l}\text { The GOB introduced this rule, making the } \\
\text { use of } 120 \text {-ft chimneys for brick kilns } \\
\text { compulsory. This requirement was } \\
\text { successfully enforced, especially in the } \\
\text { vicinity of urban areas, and most Bull's } \\
\text { Trench Kilns (BTKs) were upgraded to } \\
\text { FCK technology. }\end{array}$ \\
\hline 2007 & $\begin{array}{l}\text { GOB Notification } \\
\text { on brick kiln }\end{array}$ & $\begin{array}{l}\text { This notification stated that environmental } \\
\text { clearance certificates would not be renewed, } \\
\text { if the owners did not shift to alternative fuel } \\
\text { and improved technologies by } 2010 \text {. }\end{array}$ \\
\hline
\end{tabular}

5 Brick Burning (Regulation) Act, Act no: 8/1989.

6 Environment Conservation Rules-1997, SRO No. 47-Law/97.

7 Some BTKs continue to operate even now (anecdotal reports), albeit illegally. 


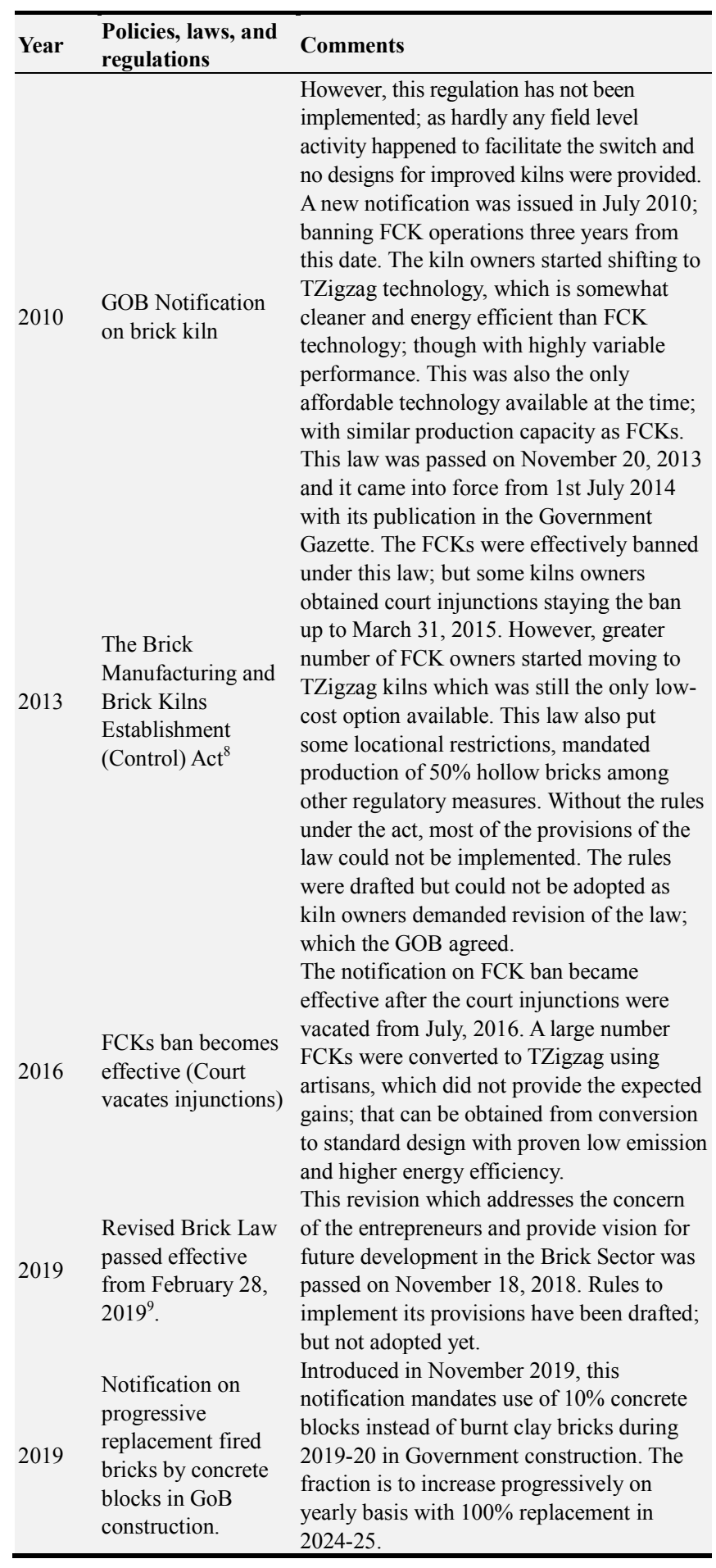

Under regulatory pressure, the existing kiln owners started moving mainly to low cost TZigzag kilns; especially after the adoption of 2013 Brick Act.

\section{Developments Brick Kiln Technology and Implementation}

The use of fired bricks in construction in the region

8 Brick Making and Kiln Construction (Control) Act of 2013; Act no. 59/2013. 9 Brick Making and Kiln Construction (Control) Revision Act; Act no. 1/2019. constituting Bangladesh, dates to time immemorial. Information on the different type of brick kilns used so far in the country are provided here in Table 2; detailing on what has been provided earlier. More details on emission data are given in the next section.

Table 2. Brief information on the Brick Kiln technologies used so far in Bangladesh.

\begin{tabular}{|c|c|c|c|}
\hline SI. & $\begin{array}{l}\text { Type of } \\
\text { Kiln }\end{array}$ & Description & Comments \\
\hline 1 & CLAMP & $\begin{array}{l}\text { The earliest kilns were CLAMPs, } \\
\text { and dates to time immemorial. In } \\
\text { the CLAMPS, green bricks are } \\
\text { stacked with fuel (wood/coal) in a } \\
\text { traditional manner, sealed with a } \\
\text { clay layer on the surface and fired } \\
\text { from the bottom. Once the fire is } \\
\text { out, CLAMP is dismantled for the } \\
\text { bricks. }\end{array}$ & $\begin{array}{l}\text { These are still being } \\
\text { used in remote areas } \\
\text { where transportation is } \\
\text { difficult. Bricks } \\
\text { produced are of poor } \\
\text { quality (i.e., a large } \\
\text { fraction of bricks } \\
\text { produced do not meet } \\
\text { quality standards). }\end{array}$ \\
\hline 2 & $\begin{array}{l}\text { Bull } \\
\text { trench } \\
\text { kilns } \\
\text { (BTK) }\end{array}$ & $\begin{array}{l}\text { The Bull trench kilns (BTK) are } \\
\text { continuous production elliptical } \\
\text { kilns, with movable sheet-metal } \\
\text { chimneys (usually } 30 \mathrm{ft} \text { high) and } \\
\text { a moving fire zone. The BTKs } \\
\text { have been around for nearly a } \\
\text { century. The average production } \\
\text { capacity is around } 20-40,000 \\
\text { bricks per day. }\end{array}$ & $\begin{array}{l}\text { BTKs are still used } \\
\text { occasionally in rural } \\
\text { areas, although illegal. } \\
\text { The emission levels } \\
\text { are very high. The } \\
\text { quality of bricks } \\
\text { produced meet the } \\
\text { Bangladesh standards } \\
\text { except for a small } \\
\text { fraction. }\end{array}$ \\
\hline 3 & $\begin{array}{l}\text { Fixed } \\
\text { Chimney } \\
\text { Kiln } \\
\text { (FCK) }\end{array}$ & $\begin{array}{l}\text { FCK design is an improved } \\
\text { version of BTK with a } 120-130 \mathrm{ft} \\
\text { chimney at the center of the kiln. } \\
\text { These have been around for about } \\
\text { half a century, since the nineteen } \\
\text { seventies. The average production } \\
\text { capacity is also around } 40,000 \\
\text { bricks per day. Average SPM } \\
\text { emission level is }>1000 \mathrm{mg} / \mathrm{m}^{3} \\
\text { and the average coal consumption } \\
\text { per } 100,000 \text { standard size bricks } \\
(230 \times 110 \times 76 \mathrm{~mm}) \text { is around } 20 \\
\text { tons }{ }^{11} \text {. }\end{array}$ & $\begin{array}{l}\text { These kilns provide } \\
\text { better dispersion of } \\
\text { emitted pollutants and } \\
\text { leading to reduced } \\
\text { local pollution and } \\
\text { have been the } \\
\text { mainstay of brick } \\
\text { production and started } \\
\text { decreasing in number } \\
\text { since ban in } 2013 \text {. } \\
\text { Most bricks produced } \\
\text { in these kilns meet the } \\
\text { national quality } \\
\text { standard. }\end{array}$ \\
\hline & & $\begin{array}{l}\text { The TZigzag kilns are basically } \\
\text { similar to FCKs; but rectangular } \\
\text { in shape with zigzag arrangement } \\
\text { of bricks with longer flue gas } \\
\text { path; with forced air circulation, } \\
\text { and chimney on one side the kiln. }\end{array}$ & $\begin{array}{l}\text { The SPM emission has } \\
\text { been found to be } \\
\text { highly variable in } \\
\text { these kilns at } 504 \pm 255 \\
\mathrm{mg} / \mathrm{m}^{3} \text { (i.e., for } 10 \\
\text { kilns). The bricks }\end{array}$ \\
\hline & $\begin{array}{l}\text { Traditional } \\
\text { Zigzag }\end{array}$ & $\begin{array}{l}\text { The Zigzag/Habla kiln design was } \\
\text { developed in Germany and it was }\end{array}$ & $\begin{array}{l}\text { produced in these kilns } \\
\text { (i.e., a high fraction) }\end{array}$ \\
\hline 4 & $\begin{array}{l}\text { kiln } \\
\text { (TZigzag) }\end{array}$ & $\begin{array}{l}\text { contemporary to BTK. The Indian } \\
\text { version of the kiln was introduced } \\
\text { in Bangladesh in the } 2000 \text { s. The } \\
\text { average production capacity is } \\
\text { also around } 40,000 \text { bricks per day. } \\
\text { The average coal consumption is } \\
\text { around } 15 \text { tons per } 100,000 \\
\text { standard bricks. }\end{array}$ & $\begin{array}{l}\text { meet the national } \\
\text { quality standard. } \\
\text { TZigzags have shorter } \\
(55-60 \mathrm{ft}) \text { chimneys } \\
\text { compared to } 120 \mathrm{ft} \text { for } \\
\text { the FCKs. Under } \\
\text { regulatory pressure } \\
\text { about } 60 \% \text { of the }\end{array}$ \\
\hline
\end{tabular}

10 The Bangladesh standard (BDS208: 2002) for brick quality are specified in terms of crushing strength and water absorbance (i.e., crushing strength of $175 \mathrm{Kgf} / \mathrm{cm}^{2}$ or $2500 \mathrm{PSI}$ and $15 \%$ water absorbance).

11 Specific data on kilns' coal consumptions and emissions are given in table 3 . Low emission kilns are defined here as kilns with emission level of SPM $<250$ $\mathrm{mg} / \mathrm{m}^{3}$. It may be noted that $250 \mathrm{mg} / \mathrm{m}^{3} \mathrm{SPM}$ standard has been adopted in India. 


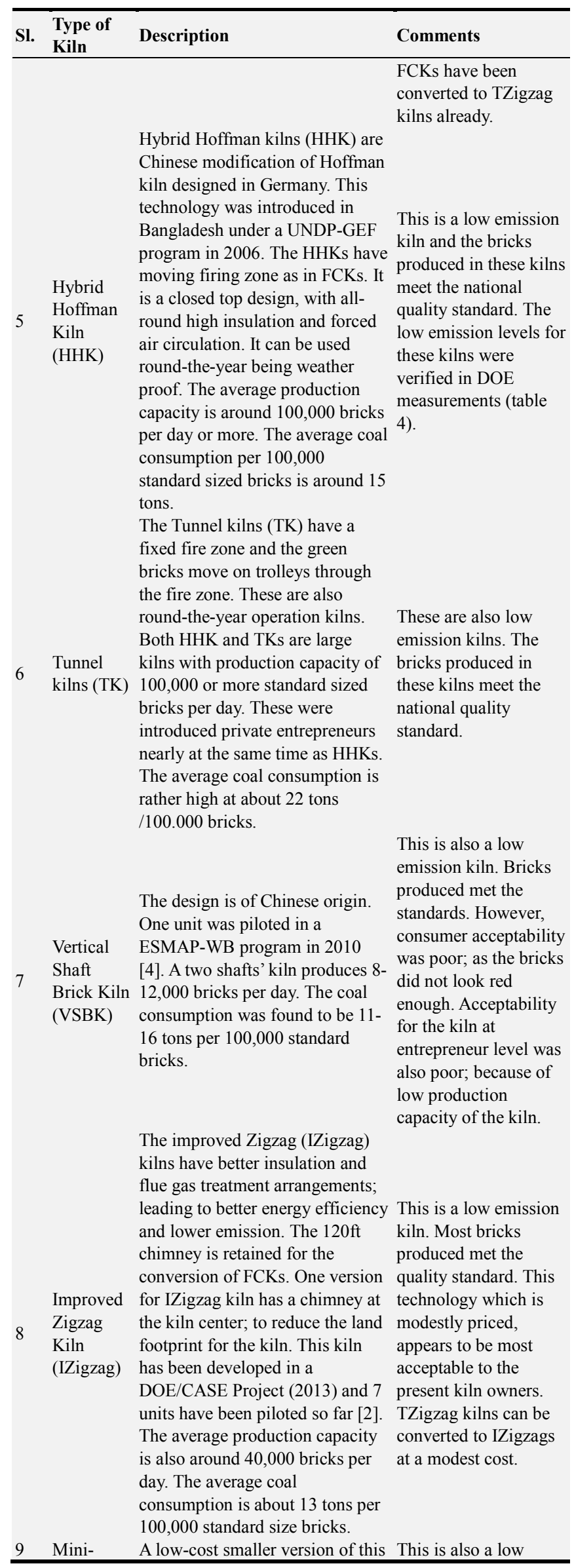

\begin{tabular}{|c|c|c|c|}
\hline SI. & $\begin{array}{l}\text { Type of } \\
\text { Kiln }\end{array}$ & Description & Comments \\
\hline & $\begin{array}{l}\text { Hybrid } \\
\text { Hoffman } \\
\text { Kiln } \\
\text { (MHHK) }\end{array}$ & $\begin{array}{l}\text { HHK kiln has been developed in } \\
\text { the DOE/CASE project (2013) } \\
\text { and } 3 \text { units have been piloted. The } \\
\text { average production capacity is } \\
\text { also around } 40,000 \text { bricks per day. } \\
\text { The average coal consumption is } \\
\text { about } 11 \text { tons per } 100,000 \\
\text { standard size bricks. }\end{array}$ & $\begin{array}{l}\text { emission kiln. This } \\
\text { type of kiln is costlier } \\
\text { than the IZigzag } \\
\text { design. However, this } \\
\text { can be used for round- } \\
\text { the-year production, if } \\
\text { constructed on land } \\
\text { above flood level. } \\
\text { Bricks produced meet } \\
\text { the standards. }\end{array}$ \\
\hline 10 & $\begin{array}{l}\text { Mini- } \\
\text { Tunnel } \\
\text { Kiln } \\
\text { (MTK) }\end{array}$ & $\begin{array}{l}\text { MTK is a low-cost smaller } \\
\text { version of the Tunnel kiln. This } \\
\text { Kiln has also been developed in } \\
\text { the DOE/CASE project (2012)[3] } \\
\text { and this has not been piloted yet. } \\
\text { It has a production capacity of } \\
20,000 \text { bricks per day and two } \\
\text { units can provide same capacity } \\
\text { of FCKs. }\end{array}$ & $\begin{array}{l}\text { This design is yet to be } \\
\text { piloted. It is a lower } \\
\text { cost smaller version of } \\
\text { the Tunnel kiln, but } \\
\text { costlier than the } \\
\text { IZigzags. However, } \\
\text { this can be used for } \\
\text { round-the-year } \\
\text { production. }\end{array}$ \\
\hline
\end{tabular}

The development in the brick sector under regulatory pressure essentially moved a significant fraction of FCKs to traditional Zigzag (TZigzag) kilns; with some improvement in fuel saving and some emissions reduction which is highly variable. This happened because DOE regulation only required move to cleaner technology; without quantitative standards for fuel efficiency and emission. Standard low-cost designs for cleaner kilns with production capacity comparable with FCKs, were also not available [5]. Faced with such realities in the brick industry and unwillingness or lack of capacity of the existing kiln owners to move to larger HHK or TK technologies, the move to TZigzag became the only feasible option. The move to HHK or Tunnel kilns by the FCK owners did not happen due to high investment requirements. The owners of the HHK kilns or Tunnel kilns are mostly new entrepreneurs with large capital resources with access to bank financing. These kilns are located on lands above flood level, operated round the year with regular employees and satisfy all the requirements for small/medium industry; thus qualifying for bank financing. However, after the initial flurry, the investment in these larger kilns have slowed down.

Therefore, the DOE under its CASE Project moved to improve the traditional Zigzag kilns design incrementally. The design is such that direct conversion of FCKs to IZigzags can also be done by retaining the $120 \mathrm{ft}$ chimney; which is the only major investment in FCKs. The existing chimney retention saves capital loss by the existing FCK owners. In parallel, work was undertaken to develop designs for smaller HHK and TK with capacity similar to FCKs (i.e., 40,000 bricks/day) at lower costs [2, 3]. So far, seven of the designed IZigzags have been piloted in different areas in the country. Three MHK designs have also been piloted in three different areas. The piloting was done with the participation of kiln owners; who were selected through open advertisements. The DOE appointed consultants provided technical assistance for the conversion of FCKs to IZigzags and construction of the MHKs. A grant (BDT one million) was provided to each kiln owner to improve work 
environment for the workers in the kiln; which included provisions for drinking water, dining, childcare and education, accommodation and sanitary facilities.

It is to be noted that brick quality for IZigzags and TZigzags are found to be similar to FCKs with crushing strength of 2600-3300 PSI compared to Bangladesh standard for clay bricks of 2500 PSI $\left(175 \mathrm{kgf} / \mathrm{cm}^{2}\right)$. The chemical analysis [2] showed that the major content of soils used were $\mathrm{SiO}_{2}(59-$ $69 \%), \mathrm{Al}_{2} \mathrm{O}_{3} \mathrm{~m}(14-18 \%), \mathrm{Fe}_{2} \mathrm{O}_{3}(5-6.5 \%)$ and $\mathrm{CaO}(0.4-$ $2.6 \%)$. Particle size analysis showed that the dominant fraction belonged to $2-20 \mu \mathrm{m}$ size being in the $35-71 \%$ range.

The time evolution of the share of different technologies in the brick sector in Bangladesh is shown below in table 3.

Table 3. Changes in the Kiln technology mix 2009-2018 [1].

\begin{tabular}{|c|c|c|c|c|c|c|c|c|c|}
\hline \multirow{2}{*}{ SI. } & \multirow{2}{*}{ Year } & \multirow{2}{*}{$\begin{array}{l}\text { Number of } \\
\text { Brick Kiln }\end{array}$} & \multirow{2}{*}{ FCKs } & \multicolumn{5}{|c|}{ No of Improved kilns } & \multirow{2}{*}{$\begin{array}{l}\text { \% of Improved Kilns } \\
\text { including TZigzag }\end{array}$} \\
\hline & & & & Zigzags & HHKs & Tunnel & Other Tech. & Not in operation & \\
\hline 1 & 2009 & 4880 & 4500 & 150 & 30 & 0 & 200 & - & 3.69 \\
\hline 2 & 2014 & 6,805 & 3498 & 2,983 & 64 & 40 & 2 & - & 45.39 \\
\hline 3 & 2015 (Nov) & 6,941 & 3426 & 3,389 & 71 & 40 & 2 & - & 50.45 \\
\hline 4 & 2017 (Jan) & 6,646 & 2541 & $4,108 *$ & 73 & 43 & 5 & - & 63.63 \\
\hline 5 & 2018 (Nov) & 7,902 & 2814 & $4,671 *$ & 73 & 43 & 299 & 631 & 60.57 \\
\hline
\end{tabular}

*Includes 7 IZigzags and 3 mini MHHKs of DOE design.

The energy consumption and emission data for converted and constructed kilns were measured for the piloted kilns; by TA consultants for piloting appointed by the DOE. A set of energy and emission data were also obtained through measurements [6] by employing an independent consultant (i.e. BCSIR) for all the technologies in operation in the country. The data from these measurements are given in Table 4. It can be seen from the SPM emission data in the table 4, that in all the newer technologies (i.e., IZigzag, MHHK, HHK and, TK), the SPM emission standard of $250 \mathrm{mg} / \mathrm{m}^{3}$ can be met. DOE is also mulling revision of SPM emission standard to $250 \mathrm{mg} / \mathrm{m}^{3}$ in the light of the new developments. In fact, as seen from table 4, IZigzags, MHHKs, HHKs and TKs can meet 200 $\mathrm{mg} / \mathrm{Nm}^{3}$ emission standard for SPM at 2 standards deviations ( 2 sigma(26)) level; i.e., $>95 \%$ of the kilns will meet the standard. With the availability of standards designs from DOE, the FCKs and TZigzag kilns can now be retrofitted to these designs to meet the revised standard at low cost.

Table 4. Coal Consumption (ton/100,000 standard bricks) and Emissions $\left(\mathrm{mg} / \mathrm{Nm}^{3}\right)$ from Brick Kilns in Bangladesh.

\begin{tabular}{|c|c|c|c|c|c|c|c|c|}
\hline Coal use/ Emission & $\begin{array}{l}\text { Baseline } \\
\text { FCK (5)* }\end{array}$ & $\begin{array}{l}\text { TZigzag } \\
(10)^{*}\end{array}$ & $\begin{array}{l}\text { TZigzag } \\
(\mathbf{1 0})^{* *}\end{array}$ & IZigzag (7)* & $\begin{array}{l}\text { IZigzag } \\
(7)^{* *}\end{array}$ & МHНК ** & HHK $^{* *}$ & TK** \\
\hline Coal use (tons/ 100,000 Std. bricks) & $20.1 \pm 0.6$ & $17.9 \pm 0.9$ & $15.3 \pm 1.8$ & $11.2 \pm 1.7$ & $13.3 \pm 1.3$ & $10.5 \pm 1.1$ & $14.8 \pm 5.3$ & $21.5 \pm 4.9$ \\
\hline$\%$ of Baseline & 100 & $89 \pm 4$ & $76 \pm 9$ & $56 \pm 8$ & $66 \pm 8$ & $52 \pm 5$ & $74 \pm 26$ & $107 \pm 24$ \\
\hline $\mathrm{SPM}\left(\mathrm{mg} / \mathrm{m}^{3}\right)$ & $1103 \pm 95$ & $243 \pm 260$ & $504 \pm 255$ & $71.2 \pm 35.5$ & $124 \pm 12$ & $131 \pm 19$ & $54 \pm 7$ & $123 \pm 25$ \\
\hline$\%$ of Baseline & 100 & $22 \pm 24$ & $46 \pm 23$ & $6.5 \pm 3.2$ & $11.2 \pm 3.4$ & $11.9 \pm 1.7$ & $6.9 \pm 2.9$ & $8.6 \pm 3.6$ \\
\hline SPM Std. at 26 level $\left(\mathrm{mg} / \mathrm{m}^{3}\right)$ & 1293 & 763 & 1014 & 142 & 148 & 169 & 68 & 173 \\
\hline $\mathrm{SO}_{2}\left(\mathrm{mg} / \mathrm{m}^{3}\right)$ & $2658 \pm 1503$ & $2118 \pm 1668$ & $550 \pm 318$ & $<\operatorname{MDL}(100)$ & $141 \pm 121$ & $46 \pm 5$ & $57 \pm 61$ & $26 \pm 16$ \\
\hline$\%$ of Baseline & 100 & $80 \pm 63$ & $20.7 \pm 12$ & - & $21 \pm 4.6$ & $2 \pm 0.2$ & $2.1 \pm 2.3$ & $1.0 \pm 0.6$ \\
\hline
\end{tabular}

*Measurements in the piloting study [2]. **Measurements by independent consultant under DOE Contract [6]

The coal consumption obviously depends on coal calorific value. The average calorific values for coal used in piloting were found to be: $19.7 \pm 0.9 \mathrm{MJ} / \mathrm{kg}$ with Range: $15.6-21.7 \mathrm{MJ} / \mathrm{kg}$; and the average Sulfur content was: $2.1 \pm 1.4 \%$ with Range: $0.61-4.47 \%$. The coal used came from Bangladesh, India, Indonesia, South Africa and Russia.

The improvement in energy efficiency in the IZigzag performance has been obtained by improving kiln insulation to reduce heat loss. The use of longer length water filled gravity settlement chamber and water-based scrubber, have contributed to reduced emissions. There are two designs for IZigzags; one with chimney on the side as in the TZigzags and other with chimney at the center with redesigned kiln-island and a U-shaped gravity settlement chamber. The centerchimney design reduces the land footprint of the kiln and is suited for kilns with no space for building the chimney on one side. In both the designs, the $120 \mathrm{ft}$ FCK chimney is retained. The dismantling and reconstruction of FCK to IZigzag with chimney on the side costs about BDT 4.6 million (i.e., about USD 55,000.); as estimated from 7 pilots implemented so far. TZigzags can be converted IZigzags at much lower cost probably at $30-50 \%$ of this amount. Average heat loss for the
7-IZigzags through different routes are shown in Table 5 along with the data for FCKs and TZigzags. It can be seen, that in the IZigzag's heat losses are reduced considerably; leading to greater energy efficiency. Both the MHK and MTK designs are closed top type; and MHK's have been found to be better in terms of fuel efficiency compared to IZigzag design; as most of the heat losses occur through the top of the kilns [2].

Table 5. Sources of heat loss (average of 7-IZigzag Pilots) during the operation $^{12}$

\begin{tabular}{llll}
\hline Type of loss & FCK & TZigzag & IZigzag \\
\hline Heat Loss at the top of cooling area (\%) & 22.1 & 15.7 & 9.8 \\
Heat Loss at the top of firing area (\%) & 11.1 & 9.3 & 5.0 \\
\hline
\end{tabular}

12 One-foot thick plastic clay is also used at the bottom of the IZigzag kilns to stop capillary water seepage; which may also improve the bottom insulation somewhat and reduce heat-loss to the ground, but this has not been measured. 


\begin{tabular}{llll}
\hline Type of loss & FCK & TZigzag & IZigzag \\
\hline Heat Loss at the top of drying area (\%) & 4.6 & 2.9 & 0.6 \\
Heat Loss through outer wall surface \% & 11.7 & 8.4 & 2.8 \\
Total Heat Loss (\%) & 49.5 & 36.3 & 18.2 \\
\hline
\end{tabular}

With the availability of the standard designs from DOE, coupled with revised energy efficiency and emission standards; the Bangladesh brick sector is poised for a major improvement both emission and energy efficiency wise. However, this development by itself will not ease the air pollution situation near the major urban centers; due to clustering of large number of kilns near these centers.

The growing demand of bricks in these cities due to increased urban growth, the GOB capacity to reduce or even to freeze the number of kilns may be difficult; as socioeconomic issues and other practical constraints may impede move to available cleaner technologies. Moves to enforce lower emission standards and removal of kilns to reduce cluster size, are likely to face resistance from the brick kiln lobby. One way of reducing dry season emission reduction, can be the move to round the year production. This would require land above seasonal flood level which is expensive; but this will also reduce the land footprint for brick kilns, as a single kiln of same capacity will be 3 times more productive. Some form of incentives may be needed to move the present kiln owners to accept the changed needs.

\section{Air Quality Scenarios and Developments}

The air pollution levels in Bangladesh show strong seasonal dependence. The NAAQS (National Ambient Air Quality (daily) Standards) values are exceeded for around 100 days per year, mostly during dry months (Nov-March). From health point of view PM2.5 is the main pollutant and it is the main determinant of AQI (Air Quality Index); now published fairly regularly for 8 large cities in the country. This is illustrated in figure 1 below for PM2.5 levels in the Dhaka area with daily standard of $65 \mu \mathrm{g} / \mathrm{m}^{3}$.

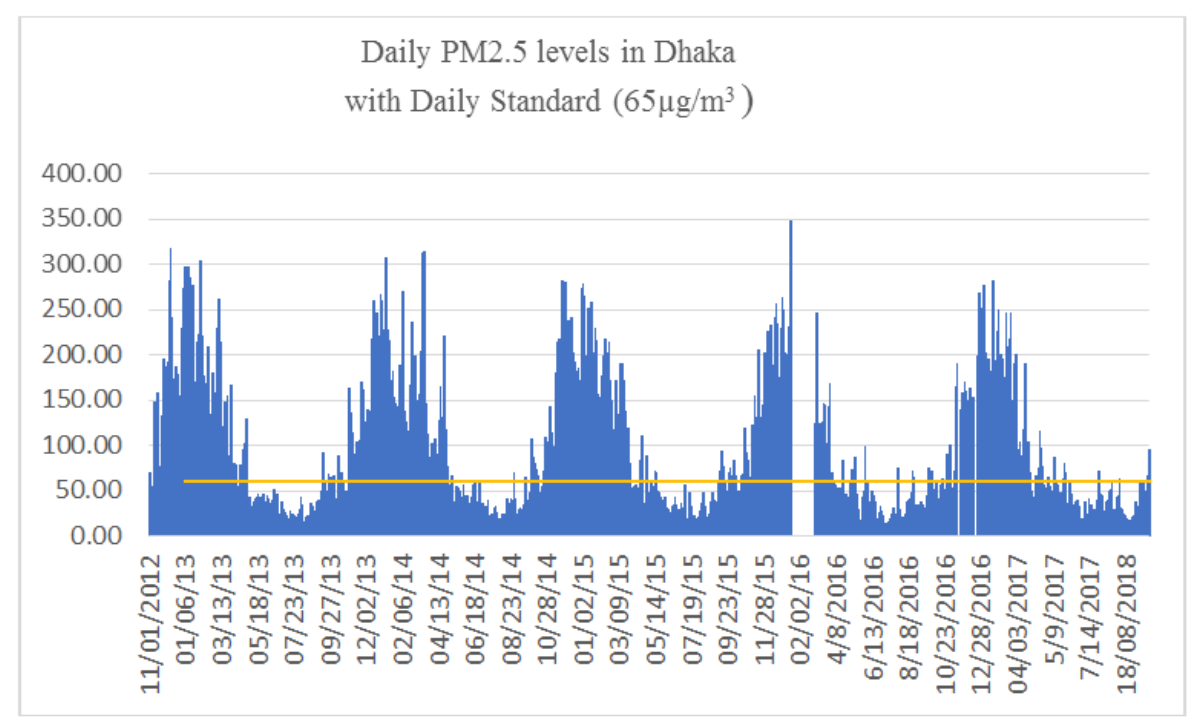

Figure 1. Seasonal Variation in Ambient PM2.5 $\left(\mu \mathrm{g} / \mathrm{m}^{3}\right)$ air pollution levels in Dhaka (Source: DOE Data Archives (2018)).

The available source apportionment data from DOE, show that major contributors of the PM2.5 pollution in all the four major cities in the country are the brick kilns; as shown in table 6 [7]. In the Dhaka city, PM2.5 pollution level from brick kilns has now reached to $58 \%$ of the total on yearly average basis. If only the dry season is considered, the percentage is much higher. In ten years, the share of the brick kilns to air pollution in Dhaka city has increased by about 20 percentage points to $58 \%$. In three other major cities, the contribution of brick kiln emission to PM2.5 pollution levels are found to be $36-40 \%$. Thus, it is obvious that any plan for air quality improvement in the major urban centers must address brick kiln pollution. The industrial pollution levels are also on the rise and the perineal issue of resuspended road dust is not going to abate in the absence of measures to control it.

Table 6. Source Apportionment (\%) of PM2.5 in four largest cities in Bangladesh.

\begin{tabular}{|c|c|c|c|c|c|c|}
\hline & Dhaka & & Chittagong & Khulna & Rajshahi & Comments \\
\hline Source & $2001-2$ & $2010-12$ & $2010-12$ & $2010-12$ & $2010-12$ & \\
\hline Soil dust & 1.0 & 7.6 & 2.59 & 9.0 & 8.39 & \\
\hline Road dust & - & 7.70 & 1.54 & 7.7 & 2.91 & \\
\hline Biomass Burning & 2.4 & 7.4 & 19.1 & 23.5 & 35.4 & \\
\hline Motor vehicles & 43.0 & 10.4 & 33.0 & 13.7 & 9.8 & \\
\hline $\begin{array}{l}\text { Fugitive with } \mathrm{Pb} \\
\text { content }\end{array}$ & 3.3 & 7.63 & 7.44 & 8.05 & 3.28 & Probably industrial emission \\
\hline
\end{tabular}


A look at the brick kiln source factor (Figure 2-left) for PM2.5 shows that the kilns to the north and north-west of the city contribute most to the pollution. The kilns are operated during winter (December to March); when the winds are also most from the same direction; which blow the pollution into the city.
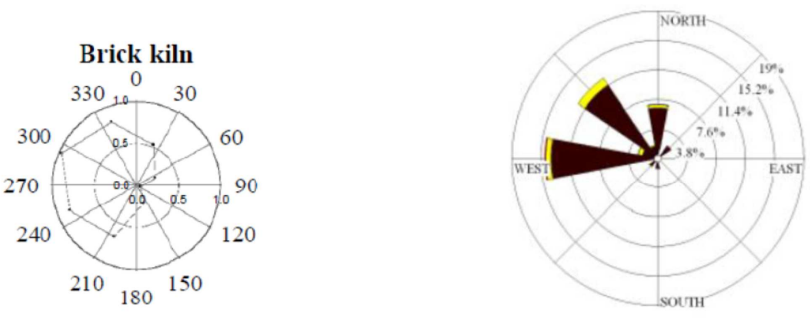

Winter

Figure 2. Dhaka Fine Particle source factor for brick kilns and Wind Rose in winter [6].

If we look at the time evolution of air pollution in Dhaka, it is seen in figure 1 that PM2.5 pollution level has stabilized and almost remained at the same level during the past five years. This has happened largely due to the decline in the vehicular pollution over the period of 15 years; as a result of various policy measures and other developments. The first of these measures was the removal of 2-stroke 3-wheelers in Dhaka in 2003. The next major step was the introduction of CNG (Compressed Natural Gas) as the transport fuel. Almost all the passenger vehicles in Dhaka are now CNG/LPG fueled. Most of the city buses $(>90 \%)$ and smaller trucks have also been converted to $\mathrm{CNG}$ fuel. The other major development was the reduction in Sulfur level in diesel fuel; which came about as refineries in the middle east which are the source of imported diesel; switched to 500ppm Sulfur diesel production, instead of previous 2000ppm. In Chittagong; vehicular emission still remains high, due to huge port related goods traffic; using heavy duty diesel fleet. Another major source urban air pollution is the biomass burning for cooking. In cities without natural gas supply, biomass is used in cooking and even in Dhaka biomass burning has increased from around $2 \%$ to about $7 \%$; due to restricted supply of NG during the past decade. The pollution due to this source is likely ease with the greater availability of LPG. Thus, the main pillar of air pollution control in all the major cities has to be emission reduction from the brick kilns; as stated earlier also.

\section{Potential Future Trajectory for Air Pollution Reduction from Brick Kilns}

It is apparent from the evidences and discussions above, that any plan for air quality improvement in Bangladesh, must address pollution from brick kilns. While tackling air pollution, other issues related to brick kilns have also to be looked at; as these issues are also of importance for public welfare. These objectives, issues and measures for emission reduction are listed below.

(i) Priority should be given for brick kiln Pollution Reduction in major urban airsheds, as the health cost is high due to large population $[7,8]$. The measures may include relocation or reduction of number of kilns in near-urban clusters, move to round the year kilns from seasonal ones among others;

(ii) Reduction in brick kiln emission through replacement of current kilns by more energy efficiency kilns, leading to significant reduction in SPM and GHG emission benefits;

(iii) Reduction/elimination of top soil use through moving to non-fired bricks; which can also lead to reduction of land footprint for the same quantity of bricks produced; and

(iv) Minimization of land footprint for the production facilities by encouraging large capacity kilns with round the year production.

The various options for actions to achieve significant gains on these issues are outlined and discussed in the following. The consequential outcome of these measures will lead to reduction of unhealthy labor practices; seasonal/migrant labor; abatement of solid waste by using as filler in non-fired bricks; and upgradation of the plants to recognized SME standards with year-round production.

\subsection{Improving Airsheds of Major Urban Centers Through Relocation of Brick Kilns}

Relocation of polluting industries out of urban airsheds has been implemented in many countries including India and China. This measure will lead to immediate reduction of air pollution from seasonal coal fired brick kilns and can be justified on cost benefit consideration [8-12]. The costs for urban air pollution have been estimated in a recent analysis and are shown Table 7 [9]. The removal of the brick kiln from Dhaka, will save more than half the cost attributable to air pollution as brick kiln contribution is estimated as $58 \%$ on yearly basis.

Table 7. Estimated Cost of Air Pollution in Urban Areas Attributable to it (\$ billions).

\begin{tabular}{lllll}
\hline \multirow{2}{*}{$\begin{array}{l}\text { PM2.5 air } \\
\text { pollution }\end{array}$} & \multicolumn{2}{c}{ Urban Bangladesh } & \multicolumn{2}{l}{ Greater Dhaka } \\
\cline { 2 - 5 } & Welfare loss & $\begin{array}{l}\text { Foregone } \\
\text { output }\end{array}$ & $\begin{array}{l}\text { Welfare } \\
\text { loss }\end{array}$ & $\begin{array}{l}\text { Foregone } \\
\text { output }\end{array}$ \\
\hline Ambient & 2.42 & 0.49 & 0.53 & 0.11 \\
Household & 1.27 & 0.25 & 0.28 & 0.06 \\
Total & 3.69 & 0.74 & 0.81 & 0.17 \\
\hline
\end{tabular}

If appropriate policy measures are taken, this action can be successfully implemented as elsewhere. This component will focus on reduction of air pollution from seasonal coal fired brick kilns, by closing/relocating of the polluting brick kilns from the vicinity (i.e., probably $20 \mathrm{~km}$ from the city boundary) of the Dhaka initially and other major urban centers with large population progressively. The kilns can be closed/relocated under the provision of Brick Burning Act of 2013, which empowers DOE to take measures to improve 
degraded Airshed. As this is unlikely to happen only under regulatory pressure; the kiln owners may have to be offered incentives for the purpose; which may include 4 permits and compensation for capital asset loss. The owners may be issued with a permit [13], which has been successfully used elsewhere; for each of the closed kiln. For each permit, an owner will be allowed to establish a low emission kiln of approved design by DOE outside the Airshed and a compensation of for lost asset (i.e., $120 \mathrm{ft}$ Chimney which is the only asset for FCKs on low land) may be provided. For every four permits (i.e., which can be purchased from owners who do not want to continue with kilns), an individual or a company will be permitted to establish one round the year kiln high capacity (i.e., at least twice the FCK production) low emission kiln with better energy efficiency on ground above flood level; or one non-fired brick plant for year-round production of similar capacity. Through this relocation, the number of kilns expected to be reduced to one-fourth of the initial number with same production, as a round the year kiln will have 3-4 times or more production than the seasonal kilns. With round the year production, the emission of pollutants will be distributed throughout year rather than in the dry season only. The problem of seasonal/ migrant labor will also be eliminated and with round the year regular employment; the kilns can be classified as regular SMEs. With substantive permanent structure, such kilns will also become bankable assets; facilitating access to finance.

\subsection{Implementation of More energy Efficient and Cleaner Brick Kilns}

Implementation of low emission and more energy efficient kilns will lead to significant reduction in PM level and GHG emissions. Progress in this area so far has already been discussed in section-3. This approach has been hampered by the non-availability of low-cost standardized design; but the situation has changed with the availability of the proven IZigzag and MHK and MTK designs from the DOE; although the MTK design is still to be piloted. All these designs can be adapted for round the year operation,

if built on land above flood level and with drying facility. The drying facility may simply be a shed with removable cover for sun-drying during non-rainy days. This has been found suitable in a previous pilot and widely used in Vietnam. Back process automation (i.e., mechanical green brick production) can result in better brick quality and can also be useful in the elimination of unhealthy labor practices (e.g., head loads). Production of hollow bricks with automated green brick production will lead to reduction in top soil use. These solutions can be pursued for low population density areas and for non-clustered kilns. Retrofitting of the TZigzag kilns to IZigzag standard can be a quick-win strategy for pollution reduction and fuel (i.e., also GHG) saving.

\subsection{Non-fired Bricks}

Increasing number of brick kilns are causing concerns apart from air pollution; these are loss of agricultural land for setting up brick kilns and the loss of top soil needed for maintaining soil fertility as brick raw material [14]. Taking note of these concerns GOB has also initiated move away from fired kilns and has issued a notification on progressive replacement fired bricks by concrete blocks in public construction in November 2019. This notification mandates use of $10 \%$ concrete blocks instead of burnt clay bricks during 2019-20 in public construction. The fraction is to increase progressively on yearly basis to $100 \%$ replacement in 2024-25. According to available information, there are about 50-60 block making plants; mostly operating in less than full capacity due to lack of demand. These plants will not be able to meet requirements if the notification is to be implemented, as all the production capacity added up may not equal even ten standard sized brick kilns. As seen from the previous experience in the brick

sector, such notifications are not easy to implement; especially in the absence of field level monitoring capacity which is currently absent.

For substantive move to non-fired brick in the country, issues in the private sector construction have to be addressed; as bulk of the construction belongs to this sector. In the private sector the non-fired bricks are yet to gain a foothold; except for some construction companies with in-house production capacity. It will be essential to expand the use in the private sector, to reduce the demand for fired clay bricks. The concrete blocks have been commercially available for many years, but the variety of products available are limited. The main barriers for market uptake are the prevailing perceptions that the concrete blocks are heavy, difficult to plaster, have higher water seepage and it is difficult to arrange for concealed work for plumbing and wiring conduits. Additionally, most masons lack familiarity with the use of concrete blocks.

Among many advantages in using non-fired bricks, the following are commonly mentioned.

(i) Elimination of top soil use;

(ii) Minimization of land footprint for the production facilities for same production due to round the year production;

(iii) Drastic reduction in direct PM and GHG emission;

(iv) Elimination of unhealthy labor practices and seasonal labor;

(v) Use of waste material as filler; and

(vi) Recognition of the plants as SMEs due year-round production and employment.

It will be necessary to address the supply constraints by expanding non-fired brick production and the product variety at competitive price to encourage greater use. The production has to be scaled up quickly; if the time-lines envisaged in the notification are to be adhered. Going by the international experience, especially in China and India, two more technologies can be gainfully pursued in Bangladesh, in addition to the concrete blocks; for expansion of the uptake of non-fired bricks especially by the private sector. These are the Lime-Sand Bricks (LSB) and AAC (Autoclaved Aerated 
Concrete) blocks technologies.

The LSBs, which are also called calcium-silicate bricks; lime is the binding material for the silicate materials. The raw materials for calcium-silicate bricks include lime mixed in an appropriate proportion with sand. Waste material can be added in the mixture which is an added advantage. The properties of these bricks are very similar to clay bricks and in addition these can be made in different colors. Large automated plants for LSB production are also available in the international market. Such plants will reduce the land footprint compared to existing kilns for same production quantity.

The AAC (Autoclaved Aerated Concrete) Block is a light and porous building material. It has light weight, high insulation, fire resistance and other advantages. It can be used in both common and industrial buildings. The main material for production will be sand; for which supply chain already exists in the country. The other ingredients are also locally available. Only one ingredient i.e., aluminum powder will need importation. Like LSB, large automated plants are also available for AAC production in the international market (e.g., from China, Germany ${ }^{13}$ and others).

\subsection{Large Scale Fired Brick Industrial Kilns}

A good beginning in this sector started more than 30 years back with a number of natural gas (NG) fired Hoffman and Tunnel kilns; which were very clean in terms of emission and had many advantages. The progress was halted due to nonavailability of NG. Some large coal fired HHK (Hybrid Hoffman kilns) and Tunnel kilns have been built but the progress is slow; due to high capital outlay requirements. These are anecdotal reports of high emission from these kilns; as some of these were implemented without proper technical supervision. Even, a few have been closed or abandoned. The mechanized round the year HHKs and Tunnel kilns do offer huge potential gains on pollution reduction and on other fronts. These will reduce land footprint as one kilns can replace as many as 8-10 FCKs. Pollution during dry season will be reduced with round the year production. Hollow bricks can be produced to conserve top soil. Labor working condition will improve with the elimination of unhealthy physical work and seasonal/migrant labor problem will be eliminated. With the growth of large industrial kilns, the smaller kilns may become noncompetitive and will be replaced by more economically viable and less polluting technologies as happened in China.

\section{Discussions}

The trends, evidences and progress in brick making in Bangladesh during the past 30 years, show rather slow progress in terms of pollution abatement and energy efficiency improvement. It is also seen that regulatory changes do not lead to desired changes; unless socioeconomic conditions are right and enough incentives are

13 https://www.wkb-systems.com/en/contact.html available for the field level actors. There have always been demands for cleaner brick kilns from the communities directly impacted by the pollution. Once this demand was taken up by the civil society and environmental activists, the awareness on the harmful impacts of brick kiln pollution started to increase at the national level and among population at large. People started to understand the reasons for the high pollution from the brick kilns; the environmental activists started going to courts for remedy. The adversaries were the brick kiln owners; who were afraid of losing their tradition business of the brick making. The kiln owners formed associations to lobby and protect their business. Most of the kiln owners lacked capital resources to upgrade their kilns; as affordable technologies were not available. In the meanwhile, air pollution in the large cities increased to intolerable level due to urban growth. This happened due to emergence of large brick kiln clusters near the larger cities, due growth in the demand for bricks from the cities. The concomitant problems with migrant labor and occupational health started to grow also in equal pace.

While government moving ahead with regulatory measures driven by public demand, created considerable push factor for the kiln owners to move to cleaner brick making; however, the corresponding pull factors such as availability of standardized cleaner kiln designs and fiscal support for change could not be provided. The assumption that the market will provide the solutions under high regulatory pressure, also turned out to be untenable. Gradually, stakeholder started getting together, the courts started giving directives for pollution abatement and the international donors were also sensitized to help-out with the air pollution and the other associated problems. With these developments, both the push factor and pull factors for air pollution abatement have started to come together and the situation on the ground has started moving in the positive direction; albeit slowly. DOE has now developed three kilns with substantially higher energy efficiency and lower emissions; that have similar capacities to FCKs and can be implemented at affordable cost. However, the rollout is yet to happen. DOE has piloted only seven kilns so far through some incentives; it is necessary to workout the measures to make the rollout widespread.

On the larger kilns some progress has been made through import of technology for HHKs and TKs; but progress is also slow in this front. These kilns being round the year operation has many advantages as discussed in the paper. The slow down in growth needs to be studied to incentivize the larger especially TKs; as there are reportedly issues with the technical support for HHKs.

On the non-fired brick front, GOB has rolled out regulatory measures recently. As discussed in the paper, the problems for growth on this front appear to be perceptional on the part of the customers and lack of ready market for the manufacturers. The existing small-scale concrete block industries, have been struggling for more than 15 years and some have even closed. One remedy may be the increase in the variety of non-fired bricks suited to specific use, so that 
customers have better choice for these bricks. As discussed in the paper largescale plants for LSB and AAC brick are available in the international market; but entrepreneurs are unwilling to invest in these for fear of being stuck with large inventory.

With all the activities during the past 30 years, air pollution due to brick kiln emission is still a continuing problem; that cause considerable health burden for the population and also substantial financial burden on the nation. Public investment for incentivizing cleaner brick making can be justified, because of public health and other benefits as discussed in this paper.

\section{Conclusion}

The existing situation as discussed above, calls for urgent further synergistic efforts to address the brick kiln pollution and the related issues in a comprehensive manner. In order to achieve quick all-round gains, both push as pull factors for changes have to be mobilized. What is needed, is a wellarticulated 'Theory of Change [15]' (ToC) for green and clean brick industry; which will substantially reduce the health impact of the brick kilns, reduce land footprint for kilns, reduce top soil use, reduce GHG emission and improve employment and working conditions for labor employed in the brick sector.

ToC is generally understood to be the explanation of the process of change for successful outcomes. The pathways for the change need to be identified and their logical connections to all the others need to be shown. The outcomes also need to be defined with time lines. The links between outcomes are explained by statements as to why one outcome may be a prerequisite for another. Thus, the ToC can also be thought of as a strategic planning tool with monitoring, evaluation and learning; with complex interaction among all these. A primary reason why complex programs are so difficult to evaluate, is that the assumptions that inspire them are not properly understood and how the change process will unfold is uncertain. So, it is essential that attention be focused on the early and mid-term changes needed to reach the longer-term goals. A simplified ToC for a cleaner and greener brick sector is outlined in the appendix (Table 8); without interlinks among the processes and outcomes for a period of next ten years. The ToC will need to up-graded considering the feedback processes involved. Given the political will of the GOB and the goodwill of the stakeholders, there is a good possibility that most of the strategic objectives can be realized.

\section{Acknowledgements}

The authors wish to thank the successive Director Generals, Directors of the Clean Air Sustainable Environment (CASE) Project, technical staffs and consultants of the of the Department of Environment since 2009; who were involved with the brick kiln program of the DOE, for their support in many ways. Specially acknowledged is the easy access to DOE's documents referred to here; wherefrom most of the primary data have been obtained.

\section{Disclaimer}

The findings, interpretations, and conclusions expressed in this paper are solely attributable to the authors and are not related to World Bank or the Governments of Bangladesh.

\section{Appendix}

Table 8. A simplified Theory of Change for the transformation to cleaner and greener Brick Sector in Bangladesh.

\begin{tabular}{|c|c|c|c|c|c|c|c|}
\hline SI. & Objectives & $\begin{array}{l}\text { Policy } \\
\text { Interventions }\end{array}$ & Challenges & Incentives/ supports & $\begin{array}{l}\text { Expected Outcomes } \\
\text { (3-5 Years) }\end{array}$ & Comments & $\begin{array}{l}\text { Longer Term (10 } \\
\text { years) outcomes }\end{array}$ \\
\hline 1. & $\begin{array}{l}\text { Reduction of } \\
\text { PM2.5 in } \\
\text { major urban } \\
\text { centers for } \\
\text { maximum } \\
\text { health benefits }\end{array}$ & $\begin{array}{l}\text { Mandating } \\
\text { Relocation/ } \\
\text { closing of fired } \\
\text { brick kilns within } \\
\text { 50km from city } \\
\text { centers. This will } \\
\text { only partially } \\
\text { solve the } \\
\text { problem, } \\
\text { especially } \\
\text { considering the } \\
\text { large air sheds. } \\
\text { Hence, it has to } \\
\text { be a carrying } \\
\text { capacity- based } \\
\text { approach. }\end{array}$ & $\begin{array}{l}\text { (i) Lack of incentives } \\
\text { for kiln owners; } \\
\text { (ii) Supply } \\
\text { constraints for skilled } \\
\text { workers and } \\
\text { emission control } \\
\text { devices. }\end{array}$ & $\begin{array}{l}\text { Tradable permits } \\
\text { Conditional incentives } \\
\text { such as land allocation } \\
\text { or cash for capital loss. }\end{array}$ & $\begin{array}{l}\text { Fired brick kilns } \\
\text { moved from near } \\
\text { major urban centers in } \\
3-5 \text { years. }\end{array}$ & $\begin{array}{l}\text { Policies for } \\
\text { replacement of brick } \\
\text { supply to be pursued in } \\
\text { Parallel. }\end{array}$ & $\begin{array}{l}\text { 1. Smaller high } \\
\text { emission kilns } \\
\text { will disappear } \\
\text { near large cities. } \\
\text { 2. Smaller low } \\
\text { emission kilns } \\
\text { will be limited } \\
\text { to rural areas } \\
\text { and near small } \\
\text { towns. } \\
\text { 3. Large fraction of } \\
\text { fired brick } \\
\text { production will } \\
\text { shift to larger, } \\
\text { cleaner and } \\
\text { round the year }\end{array}$ \\
\hline 2. & $\begin{array}{l}\text { Reduction of } \\
\text { PM2.5 in } \\
\text { smaller towns } \\
\text { and rural areas }\end{array}$ & $\begin{array}{l}\text { Phasing out high } \\
\text { emission kilns } \\
\text { with low } \\
\text { emission kilns of } \\
\text { approved } \\
\text { designs. }\end{array}$ & $\begin{array}{l}\text { Lack of awareness } \\
\text { among kiln owners. } \\
\text { Lack of enforcement } \\
\text { of existing } \\
\text { regulations. }\end{array}$ & $\begin{array}{l}\text { Providing designs and } \\
\text { technical assistance for } \\
\text { retrofitting their current } \\
\text { high emission kilns at } \\
\text { low cost. } \\
\text { Fixing SPM emission }\end{array}$ & $\begin{array}{l}\text { FCKs and traditional } \\
\text { zigzags to be replaced } \\
\text { within } 3 \text { years }\end{array}$ & $\begin{array}{l}\text { DOE has three designs } \\
\text { available and two have } \\
\text { already been piloted, } \\
\text { which has validated the } \\
\text { design performances } \\
\text { with about } 30 \%\end{array}$ & $\begin{array}{l}\text { operation kilns. } \\
\text { 4. Non-fired bricks } \\
\text { will constitute a } \\
\text { large fraction of } \\
\text { bricks and wall } \\
\text { materials }\end{array}$ \\
\hline
\end{tabular}




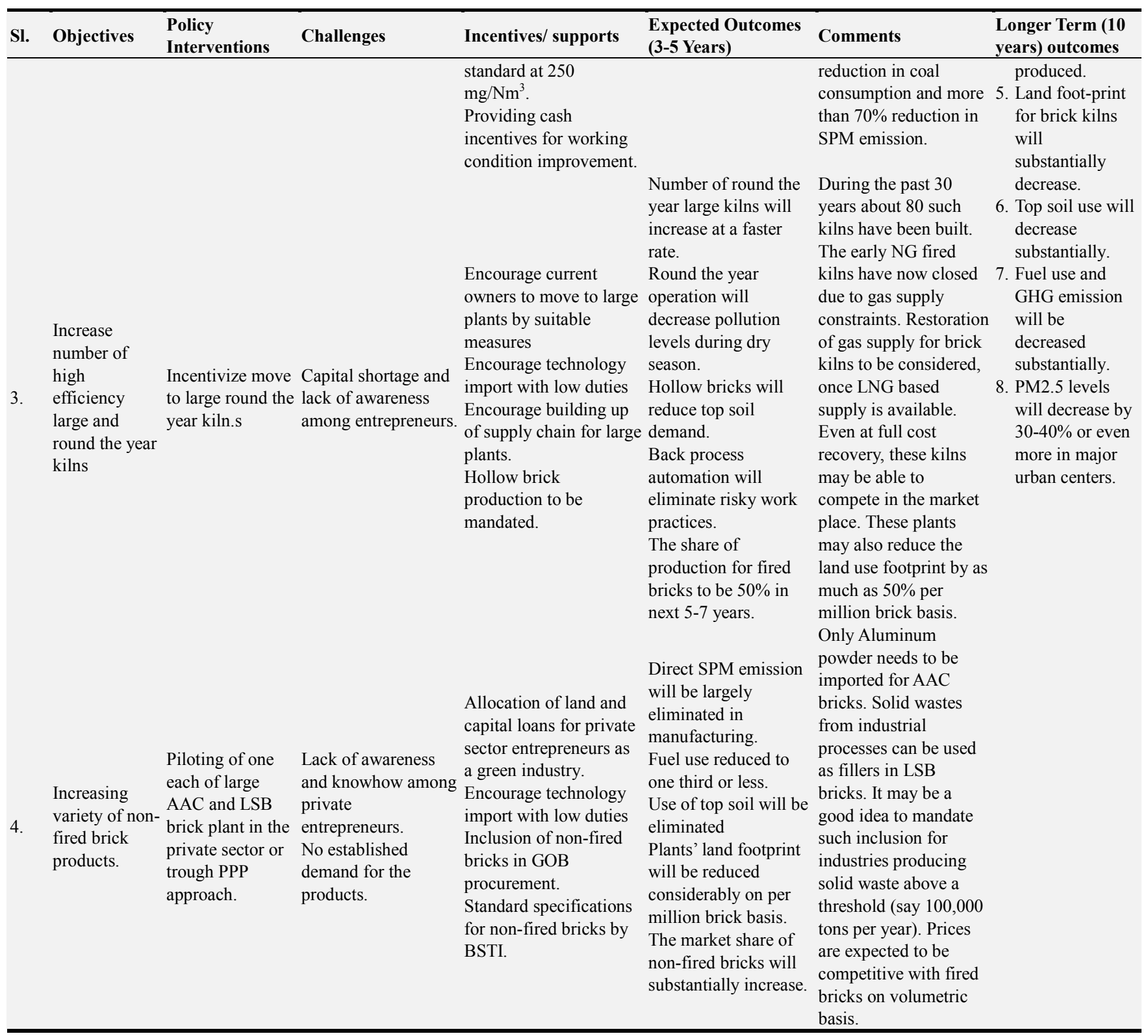

\section{References}

[1] DOE 2018A: Report S-23 CASE Project, DOE; The 2018 inventory of Brick kilns in Bangladesh prepared by JNU (Jahangir Nagar University), 2018.

[2] DOE 2017: Report on Brick kiln energy efficiency and Emission, prepared by Institute of Heat and Refrigeration Engineering, Hanoi University and Bangladesh Consultants Ltd (IHRE-BCL Consortium), CASE, DOE Report S8A (2017)

[3] DOE 2012: Report on Design and Practice of Improvement of Existing Zigzag kilns with guidelines, prepared by Xian Research and Design Institute in China of Wall and Roof materials, China and Clean Energy Alternatives. Report CASE, DOE S9A (2012)

[4] WB 2011: Introducing Energy-efficient Clean Technologies in the Brick Sector of Bangladesh, WB, Maria Sarraf, Lelia
Croitoru, M. Khaliquzzaman, Shakil A. Ferdausi and Jie Li; ESMAP Publication Series, Report No. 60155-BD, The World Bank, Washington DC.

[5] Stephen P. Luby, Debashish Biswas, Emily S. Gurley, Ijaz Hossain; Why highly polluting methods are used to manufacture bricks in Bangladesh; Energy for Sustainable Development 28 (2015) 68-74

[6] DOE 2018B: Report on Brick kiln energy efficiency and Emission, by BCSIR, DOE Contract Report no- S10 (2018).

[7] DOE 2015: Report on Identification and apportionment of Sources from Air Particulate Matter at Urban Environments in Bangladesh; Prepared by Norwegian Institute for Air Research (NILU), Report CASE, DOE S13 (2015).

[8] S. K. Guttikunda, M. Khaliquzzaman, Health benefits of adapting cleaner brick manufacturing technologies in Dhaka, Bangladesh, Air Qual Atmos Health, 7 (1), (2014).

[9] WB 2018: Bangladesh Country Environmental Analysis (2018), World Bank. 
[10] Lelia Croitoru, Maria Sarraf; Benefits and Costs of the Informal Sector: The Case of Brick Kilns in Bangladesh; Journal of Environmental Protection, 2012, 3, 476-484.

[11] Sarath K. Guttikunda \& Bilkis A. Begum \& Zia Wadud; Particulate pollution from brick kiln clusters in the Greater Dhaka region, Bangladesh; Air Qual Atmos Health (2013) 6: $357-365$.

[12] Bjorn Larsen, Benefits and costs of brick kiln options for air pollution control in Greater Dhaka, Bangladesh Priorities, Copenhagen Consensus Center, 2016; https://www.copenhagenconsensus.com/sites/default/files/lars en_outdoorairpollution.pdf

[13] Tietenberg 2004: Tradable Permit Approaches to Pollution Control: Faustian Bargain or Paradise Regained?; Tom
Tietenberg, $\quad$ http://www.colby.edu/personal/thtieten/; https://www.researchgate.net/publication/251762142_Tradabl e_Permit_Approaches_to_Pollution_Control_Faustian_Bargai n_or_Paradise_Regained

[14] Hossain, M. A., Zahid, A. M., Arifunnahar, M. and Siddique M. N. A.; Effect of brick kiln on arable land degradation, environmental pollution and consequences on livelihood of Bangladesh; J. Sci. Technol. Environ. Inform. 06 (02): 474488 | (2019).

[15] Stein et al 2014: Understanding 'Theory of Change' in International development: A review of Existing knowledge; D. Stein and C. Valters; www.theoryofchange.org/.../pdf/UNDERSTANDINGTHEOR YOFChangeSteinValters... 